\title{
Pd-catalyzed asymmetric Suzuki-Miyaura coupling reactions for the synthesis of chiral biaryl compounds with a large steric substituent at the 2-position
}

\author{
Yongsu Li, Bendu Pan, Xuefeng He, Wang Xia, Yaqi Zhang, Hao Liang, \\ Chitreddy V. Subba Reddy, Rihui Cao and Liqin Qiu*
}

\author{
Full Research Paper \\ Address: \\ School of Chemistry, Guangdong Key Lab of Chiral Molecules and \\ Drug Discovery, Sun Yat-sen University, No. 135 Xingangxi Road, \\ Guangzhou 510275, People's Republic of China \\ Email: \\ Liqin Qiu* - qiuliqin@mail.sysu.edu.cn \\ * Corresponding author \\ Keywords: \\ asymmetric catalysis; biaryls; monophosphine ligand; palladium \\ catalyst; Suzuki-Miyaura couplings
}

\author{
Beilstein J. Org. Chem. 2020, 16, 966-973. \\ doi:10.3762/bjoc. 16.85 \\ Received: 01 March 2020 \\ Accepted: 30 April 2020 \\ Published: 11 May 2020 \\ Dedicated to Professor Albert S. C. Chan on the occasion of his 70th \\ birthday. \\ Associate Editor: K. Grela \\ (C) 2020 Li et al.; licensee Beilstein-Institut. \\ License and terms: see end of document.
}

\begin{abstract}
Pd-catalyzed asymmetric Suzuki-Miyaura couplings of 3-methyl-2-bromophenylamides, 3-methyl-2-bromo-1-nitrobenzene and 1-naphthaleneboronic acids have been successfully developed and the corresponding axially chiral biaryl compounds were obtained in very high yields (up to 99\%) with good enantioselectivities (up to $88 \%$ ee) under mild conditions. The chiral-bridged biphenyl monophosphine ligands developed by our group exhibit significant superiority to the naphthyl counterpart MOP in both reactivity and enantioselectivity control. The large steric hindrance from $\pi$-conjugated ortho-substituents of the bromobenzene substrates and the $\mathrm{Pd} \cdots \mathrm{O}$ interaction between carbonyl and palladium seem essential to achieve high enantioselectivity.
\end{abstract}

\section{Introduction}

Axially chiral molecules have received much attention from chemists because of their widespread appearance in biologically active compounds [1-4] such as vancomycin [5] and korupensamine A [6] and as useful chiral ligands in asymmetric catalysis. Different strategies with various metals and phosphine ligands had been successfully employed for the efficient synthesis of this scaffold [7-22], like Hiyama [23,24], Negishi [25,26] or Suzuki-Miyaura couplings [27-36]. In these synthetic strategies, the reaction system of palladium with chiral phosphine ligands was studied fruitfully by Cammidge [37,38], Buchwald [13,28,39], Tang [40-43] and other groups [43-59]. Nevertheless, for the asymmetric formation of large steric systems such as sterically demanding biaryls still remain limitations [24], especially on how to obtain the large steric axially chiral biaryl 
with a high yield and good enantioselectivity through those coupling strategies [13]. Therefore, based on our previous research [60-65], we herein present a new method through which those large steric axially chiral biaryl compounds can be obtained in excellent yields and good enantioselectivities under mild conditions, by using brominated amides and arylboronic acids as substrates, as well as palladium and chiral-bridged biphenyl monophosphine ligands as catalysts.

\section{Results and Discussion}

2-Bromo-3-methyl- $N$-phenylbenzamide (1g) and 1-naphthylboronic acid (2a) were utilized to synthesize axially chiral compound 3g. This reaction was selected as model reaction for further optimization of Pd sources, ligands (Figure 1), solvents, bases and temperature. At first, various phosphine ligands were screened with $2.5 \mathrm{~mol} \% \mathrm{Pd}_{2}(\mathrm{dba})_{3}, 3.0$ equivalents $\mathrm{K}_{3} \mathrm{PO}_{4}$ in $\mathrm{THF}$ at $50{ }^{\circ} \mathrm{C}$ for $72 \mathrm{~h}$. The results show that the ligands have a large effect on the reaction. As listed in Table 1, the reaction was performed well and the product was obtained in $70 \%$ yield when using L1 $(R)$-MOP as the ligand, but the enantioselectivity was unsatisfactorily low ( $36 \%$ ee; Table 1 , entry 1$)$. After further examination of the ligands developed by our group (L2-L9), it was found that phosphine ligands with a large steric aryl group linked to a phosphorus atom are more effective than the ligand with a cyclohexyl group both in yield and enantioselectivity (Table 1, entries 2-7). The results show that the higher the steric hindrance of the ligand, the better the yield and enantioselectivity. In order to find out whether the 1'-substituent of the ligand has any influence on the reaction result, we replaced the methoxy group (L3) with an ethoxy group $(\mathbf{L 8})$, or a hydrogen atom (L9), which all led to a significant decrease of yield and enantioselectivity (Table 1, entries 3 vs 8 and 9). Considering the yield and enantioselectivity of the product comprehensively, $\mathbf{L} 7$ was chosen as the most suitable ligand for this reaction and under these conditions product $\mathbf{3 g}$ was obtained in $85 \%$ yield and with $78 \%$ ee (Table 1, entry 7 ). In the following investigations, it was found that $\mathrm{Pd}_{2}(\mathrm{dba})_{3}$ as palladium source,
THF as solvent and $\mathrm{K}_{3} \mathrm{PO}_{4}$ as base is the most effective combination (Table 1, entries 10-18). More results suggested that the yield varied directly proportional to the temperature, while the enantioselectivity went inversely (Table 1, entries 19-21). Therefore, $50{ }^{\circ} \mathrm{C}$ was chosen as the reaction temperature.

With the optimized reaction conditions in hand, we expanded the reaction with various functionalized starting materials, as shown in Scheme 1. Linear $N$-alkyl substituted amides were found to produce better yields than $N$-branched alkyl chain amides, though they performed similar ee values $(\mathbf{3 a}, \mathbf{3 b})$. $\mathrm{N}$-Cycloalkyl-substituted amides enabled the reaction to achieve a quantitative conversion with good ee value (97\% yield, $76 \%$ ee for $\mathbf{3 c} ; 98 \%$ yield, $75 \%$ ee for $\mathbf{3 d}$ ). The yield and ee value of an oxazolidinone amide were slightly lower than those of tetrahydropyrrolamide (3e, $\mathbf{3 f})$. Various aromatic substituted amides were investigated. The results show that electron-rich or electron-deficient substituents on the phenyl ring have no significant influence on the enantiomeric excesses of the products $(\mathbf{3 g}-\mathbf{n})$, but the best ee value was obtained for the substrate with an electron-deficient phenyl ester ( $88 \%$ ee, 3o). By changing 1-naphthaleneboronic acid to 4-substituted-1-naphthaleneboronic acids $\mathbf{3 p}, \mathbf{3 q}$ and $\mathbf{3 r}$, the enantioselectivity and the yield of the reaction decreased with the increase of the substituent on the boronic acid. When a methyl or methoxy group were present at the ortho-position of 1-naphthaleneboronic acid, the reactions were hard to move on even at $70{ }^{\circ} \mathrm{C}$. By replacing the 3-methyl group of the amide with a 3-methoxy or a 3-benzyloxy group, the yield and ee value of the reaction were still unsatisfactory though the temperature had been raised to $70{ }^{\circ} \mathrm{C}$ too (see Supporting Information File 1, Scheme S1, compounds $3 \mathrm{~s}, 65 \%$ yield, $18 \%$ ee; 3 t, $60 \%$ yield, $23 \%$ ee). In addition, phenylboric acids were also investigated, but the reaction results were not so good (see Supporting Information File 1, Scheme S1, compounds 3u, $60 \%$ yield, $11 \%$ ee; $\mathbf{3 v}, 90 \%$ yield, $0 \%$ ee).<smiles>COc1ccc2ccccc2c1-c1c(P)ccc2ccccc12</smiles>

L1: $(R)-\mathrm{MeO}-\mathrm{MOP}$<smiles>COc1cccc(Oc2cccc(OC)c2-c2c(OC)cccc2OC)c1C</smiles>

L2

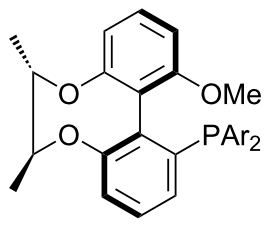

L3: $\mathrm{Ar}=\mathrm{Ph}$

L4: $\mathrm{Ar}=4-\mathrm{MeC}_{6} \mathrm{H}_{4}$

L5: $\mathrm{Ar}=3,5-\mathrm{Me}_{2} \mathrm{C}_{6} \mathrm{H}_{3}$

L6: $\mathrm{Ar}=3,5-t-\mathrm{Bu}_{2} \mathrm{C}_{6} \mathrm{H}_{3}$

L7: $\mathrm{Ar}=3,5-t-\mathrm{Bu}_{2}-4-\mathrm{MeOC}_{6} \mathrm{H}_{2}$

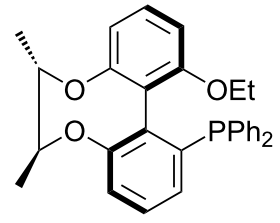

L8

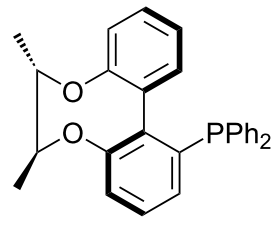

L9

Figure 1: $(R)-\mathrm{MeO}-\mathrm{MOP}$ and our ligands. 
Table 1: Optimization of reaction conditions ${ }^{a}$

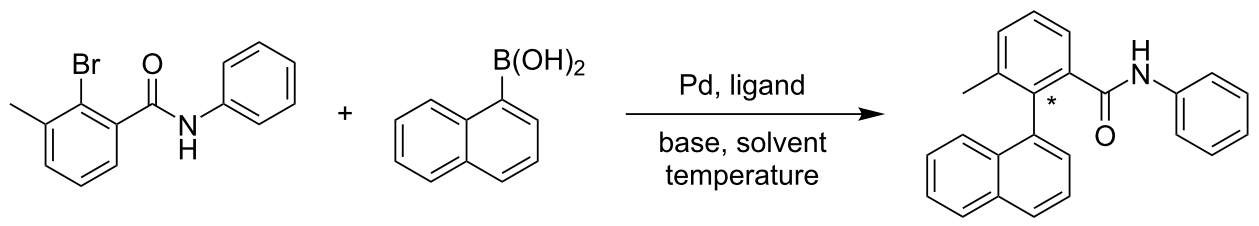

\begin{tabular}{|c|c|c|c|c|c|c|c|}
\hline Entry & Ligand & $\mathrm{Pd}$ & Solvent & Base & Temp $\left({ }^{\circ} \mathrm{C}\right)$ & Yield (\%) & ee $(\%)^{c}$ \\
\hline 1 & L1 & $\mathrm{Pd}_{2}(\mathrm{dba})_{3}$ & THF & $\mathrm{K}_{3} \mathrm{PO}_{4}$ & 50 & 70 & 36 \\
\hline 2 & L2 & $\mathrm{Pd}_{2}(\mathrm{dba})_{3}$ & THF & $\mathrm{K}_{3} \mathrm{PO}_{4}$ & 50 & 36 & 16 \\
\hline 3 & L3 & $\mathrm{Pd}_{2}(\mathrm{dba})_{3}$ & THF & $\mathrm{K}_{3} \mathrm{PO}_{4}$ & 50 & 48 & 54 \\
\hline 4 & L4 & $\mathrm{Pd}_{2}(\mathrm{dba})_{3}$ & THF & $\mathrm{K}_{3} \mathrm{PO}_{4}$ & 50 & 82 & 54 \\
\hline 5 & L5 & $\mathrm{Pd}_{2}(\mathrm{dba})_{3}$ & THF & $\mathrm{K}_{3} \mathrm{PO}_{4}$ & 50 & 83 & 63 \\
\hline 6 & L6 & $\mathrm{Pd}_{2}(\mathrm{dba})_{3}$ & THF & $\mathrm{K}_{3} \mathrm{PO}_{4}$ & 50 & 63 & 76 \\
\hline 7 & L7 & $\mathrm{Pd}_{2}(\mathrm{dba})_{3}$ & THF & $\mathrm{K}_{3} \mathrm{PO}_{4}$ & 50 & 85 & 78 \\
\hline 8 & L8 & $\mathrm{Pd}_{2}(\mathrm{dba})_{3}$ & THF & $\mathrm{K}_{3} \mathrm{PO}_{4}$ & 50 & 85 & 36 \\
\hline 9 & L9 & $\mathrm{Pd}_{2}(\mathrm{dba})_{3}$ & THF & $\mathrm{K}_{3} \mathrm{PO}_{4}$ & 50 & 64 & 37 \\
\hline 10 & L7 & $\mathrm{Pd}(\mathrm{OAc})_{2}$ & THF & $\mathrm{K}_{3} \mathrm{PO}_{4}$ & 50 & 20 & 60 \\
\hline 11 & L7 & $\mathrm{PdCl}_{2}$ & THF & $\mathrm{K}_{3} \mathrm{PO}_{4}$ & 50 & 78 & 75 \\
\hline 12 & L7 & $\mathrm{Pd}\left(\mathrm{CF}_{3} \mathrm{COO}\right)_{2}$ & THF & $\mathrm{K}_{3} \mathrm{PO}_{4}$ & 50 & 20 & 74 \\
\hline 13 & L7 & $\mathrm{Pd}_{2}(\mathrm{dba})_{3}$ & toluene & $\mathrm{K}_{3} \mathrm{PO}_{4}$ & 50 & 75 & 68 \\
\hline 14 & L7 & $\mathrm{Pd}_{2}(\mathrm{dba})_{3}$ & DME & $\mathrm{K}_{3} \mathrm{PO}_{4}$ & 50 & 45 & 70 \\
\hline 15 & L7 & $\mathrm{Pd}_{2}(\mathrm{dba})_{3}$ & DCE & $\mathrm{K}_{3} \mathrm{PO}_{4}$ & 50 & 57 & 62 \\
\hline 16 & L7 & $\mathrm{Pd}_{2}(\mathrm{dba})_{3}$ & THF & $\mathrm{Cs}_{2} \mathrm{CO}_{3}$ & 50 & 60 & 52 \\
\hline 17 & L7 & $\mathrm{Pd}_{2}(\mathrm{dba})_{3}$ & THF & $\mathrm{KF}$ & 50 & 30 & 78 \\
\hline 18 & L7 & $\mathrm{Pd}_{2}(\mathrm{dba})_{3}$ & THF & $\mathrm{CsF}$ & 50 & 53 & 74 \\
\hline 19 & L7 & $\mathrm{Pd}_{2}(\mathrm{dba})_{3}$ & THF & $\mathrm{K}_{3} \mathrm{PO}_{4}$ & 40 & 63 & 78 \\
\hline 20 & L7 & $\mathrm{Pd}_{2}(\mathrm{dba})_{3}$ & THF & $\mathrm{K}_{3} \mathrm{PO}_{4}$ & 60 & 90 & 72 \\
\hline 21 & L7 & $\mathrm{Pd}_{2}(\mathrm{dba})_{3}$ & THF & $\mathrm{K}_{3} \mathrm{PO}_{4}$ & 70 & 90 & 69 \\
\hline
\end{tabular}

aReaction conditions: 1 equiv of $N$-aryl-bromoarylamide, 2 equiv of naphthylboronic acid, $5 \mathrm{~mol} \% \mathrm{Pd}, 6 \mathrm{~mol} \%$ of ligand, 3 equiv of base, $2 \mathrm{~mL}$ solvent, $50^{\circ} \mathrm{C}, 72 \mathrm{~h}$. ${ }^{b} \mathrm{NMR}$ Yield. ${ }^{\circ}$ Characterized by HPLC with a chiral AD-H column.

More specifically, the change of the $\mathrm{R}^{1}$ group on the bromoamide compound has a weak influence on the coupling reaction. No matter it was a straight alkyl chain, a branched alkyl chain, a heterocyclic group, an electron-rich aromatic or an electron-deficient aromatic group, the reaction always performed well with high yield and good enantioselectivity. We guess that the large sterically hindered $\pi$-plane formed between a carbonyl group and a benzene ring is the guarantee of high ee values of the product $[13,39,42,57,65]$ along with the $\mathrm{Pd} \cdots \mathrm{O}$ interaction $[13,64]$ between carbonyl and palladium. The experimental results also show that the substituent of the arylboronic acid has an obvious effect on the reaction: the yield and ee value of the product decrease with the increase of the steric hindrance of the 4-substituted boronic acid.

Next, in order to confirm our speculation, the amide group of the aryl bromide was replaced with other functional groups, as shown in Scheme 2. When the amide group was changed into an amine, coupling product 5a was obtained quantitatively but without any enantioselectivity. Just a slight improvement of the ee value was found along with the introduction of bulkier substituents to the amino group (5b-d). From the reaction results, it can be seen that the $\mathrm{Pd} \cdots \mathrm{O}$ interaction $[13,64]$ between the carbonyl group and the palladium plays an important role for the reaction enantioselectivity. However, with the substitution of an ester group for the amino moiety, interestingly, the situation changed significantly. The greater the ester substituent, the better the reaction results including the product yield and ee value. When the functional group changed from methyl ester to tert-butyl ester, the reaction yield rose up from $77 \%$ to $90 \%$ and the enantioselectivity increased from $35 \%$ to $70 \%(\mathbf{5 e}, \mathbf{5 f})$. This indicates that the $\mathrm{O} \cdots \mathrm{Pd}$ interaction between the carbonyl group and the palladium is not strong enough to determine the enantioselectivity of the reaction solely, the steric hindrance from $\pi$-conjugated ortho-substituents of the bromobenzenes is also important. In addition, coupling of 2-bromo-3-nitrotoluene with 


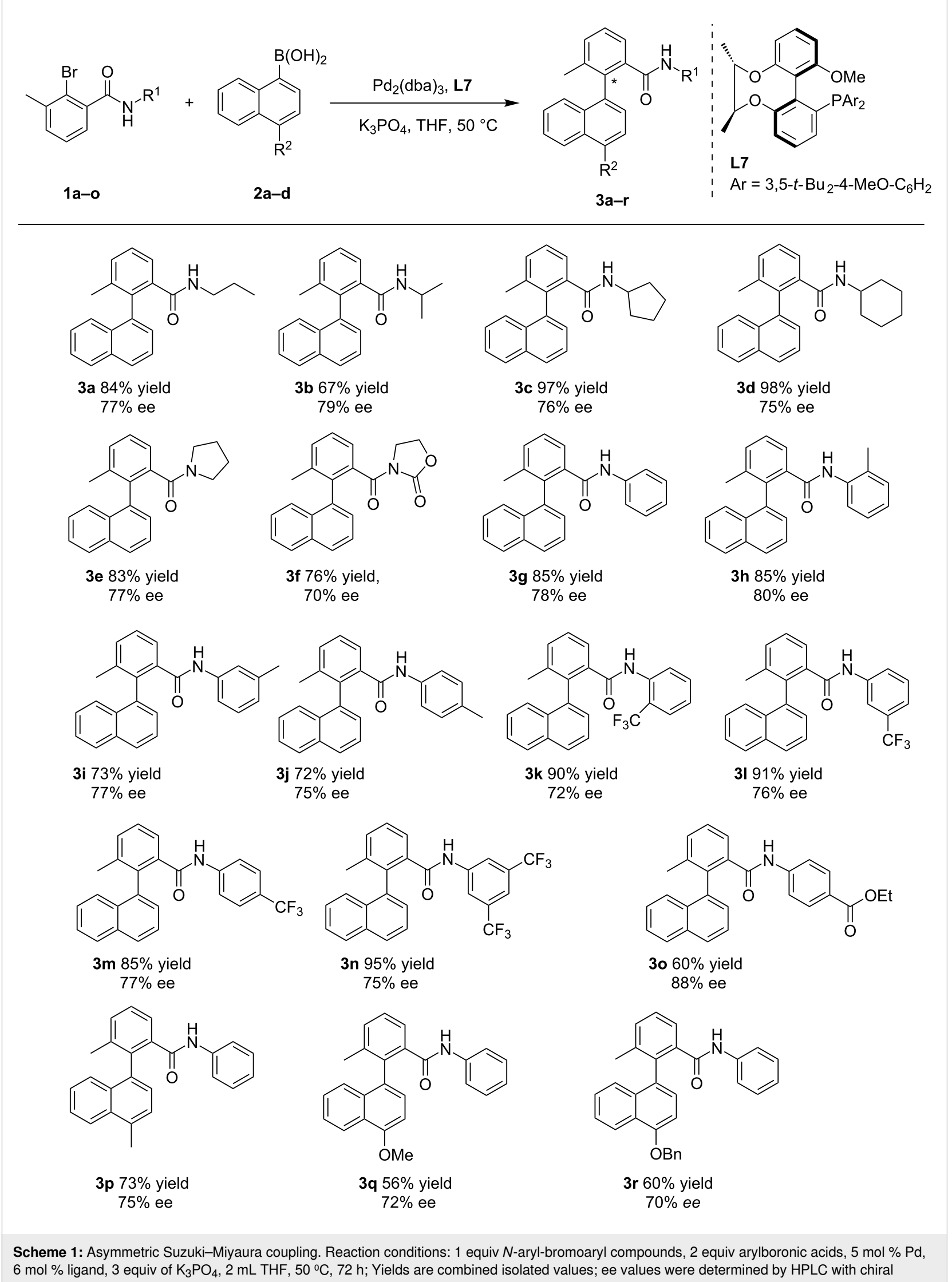


<smiles>[R]c1cccc(C)c1Br</smiles>

4a-h<smiles>[R]c1ccc(Br)c2ccccc12</smiles>

2a-c

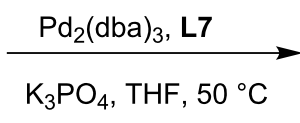

$\mathrm{K}_{3} \mathrm{PO}_{4}, \mathrm{THF}, 50^{\circ} \mathrm{C}$<smiles>[R]c1ccc(-c2c(C)cccc2C)c2ccccc12</smiles>

5a-i

$\mathrm{R}^{2}=\mathrm{H}, \mathrm{Me}, \mathrm{OMe}$<smiles>Cc1cccc(N)c1-c1cccc2ccccc12</smiles>

5a $99 \%$ yield $0 \%$ ee<smiles>COC(=O)c1cccc(C)c1-c1cccc2ccccc12</smiles><smiles>Cc1cccc(C(=O)OC(C)(C)C)c1-c1cccc2ccccc12</smiles>

5e $77 \%$ yield $35 \%$ ee<smiles>Cc1cccc(NC(C)C)c1-c1cccc2ccccc12</smiles>

5b $99 \%$ yield $10 \%$ ee<smiles>Cc1cccc(NCc2ccccc2)c1-c1cccc2ccccc12</smiles>

5c $99 \%$ yield $10 \%$ ee<smiles>Cc1cccc(NC(=O)c2ccccc2)c1-c1cccc2ccccc12</smiles>

5d $94 \%$ yield $22 \%$ ee<smiles>Cc1cccc([N+](=O)[O-])c1-c1cccc2ccccc12</smiles>

5g $98 \%$ yield $75 \%$ ee<smiles>Cc1cccc([N+](=O)[O-])c1-c1ccc(C)c2ccccc12</smiles>

5h $97 \%$ yield $83 \%$ ee<smiles>COc1ccc(-c2c(C)cccc2[N+](=O)[O-])c2ccccc12</smiles>

5i $98 \%$ yield $85 \%$ ee

Scheme 2: Asymmetric Suzuki-Miyaura coupling. Reaction conditions: 1 equiv of bromoaryl compounds, 2 equiv of arylboronic acids, 5 mol \% Pd, $6 \mathrm{~mol} \%$ of ligand, 3 equiv of $\mathrm{K}_{3} \mathrm{PO}_{4}, 2 \mathrm{~mL}$ THF, $50{ }^{\circ} \mathrm{C}, 72 \mathrm{~h}$; Yields are combined isolated values; ee values were determined by HPLC.

4-substituted or unsubstituted 1-naphthaleneboronic acids provided the corresponding products in high yields with good ee values $(\mathbf{5 g}$, $98 \%$ yield, $75 \%$ ee; $\mathbf{5 h}, 97 \%$ yield, $83 \%$ ee; $\mathbf{5 i}$, $98 \%$ yield, $85 \%$ ee) $[39,62]$. All these results show that the large steric hindrance from $\pi$-conjugated ortho-substituents of the bromobenzenes and the $\mathrm{O} \cdots \mathrm{Pd}$ interaction work together for the acquisition of high enantioselectivity. As stated before, the replacement of naphthaleneboronic acid with phenylboronic acid derivatives also resulted in poor enantioselectivities of the products (see Supporting Information File 1, Scheme S1, 3u,
$60 \%$ yield, $11 \%$ ee; $3 \mathbf{v}, 99 \%$ yield, $0 \%$ ee). This further demonstrates the importance of the steric hindrance and rigidity from the other substrate arylboronic acid. A gram-scale reaction of 1h with $2 \mathbf{a}$ went well and provided $\mathbf{3 h}$ with a slightly reduced yield and ee (75\% yield and $73 \%$ ee, Scheme 3$)$, compared with 3h in Scheme 1.

According to the coordination of axial chiral phosphine ligands $[65,66]$ and our analysis, we propose a possible intermediate structure (Scheme 4).<smiles>Cc1ccccc1NC(=O)c1cccc(C)c1Br</smiles>

$1 \mathrm{~h}$

$1.2120 \mathrm{~g}$<smiles>Oc1cccc2ccccc12</smiles>

$2 a$

$1.3760 \mathrm{~g}$

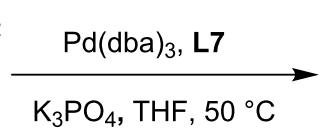<smiles>Cc1ccccc1NC(=O)c1cccc(C)c1-c1cccc2ccccc12</smiles>

3h $75 \%$ yield $73 \%$ ee

Scheme 3: Gram-scale reaction. 


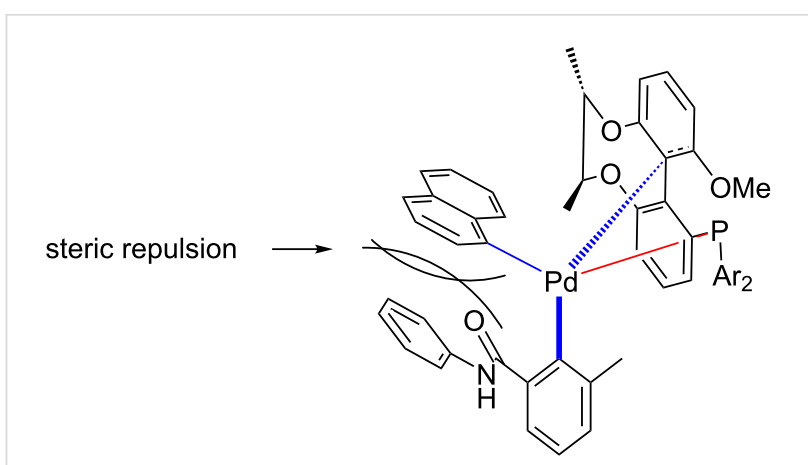

Scheme 4: Based on our analysis and speculation, a possible intermediate structure is proposed $[65,66]$.

\section{Conclusion}

In summary, a Pd-catalyzed asymmetric Suzuki-Miyaura coupling of 3-methyl-2-bromophenylamides or 3-methyl-2-bromo1-nitrobenzene and 1-naphthaleneboronic acids has been successfully developed and the corresponding axially chiral biaryl compounds were obtained in very high yields (up to 99\%) and with good enantioselectivities (up to $88 \%$ ee) under mild conditions. The chiral-bridged biphenyl monophosphine ligands developed by our group, especially L7, exhibited significant superiority to the naphthyl counterpart MOP in reactivity and enantioselectivity in the reactions. The large steric hindrance from $\pi$-conjugated ortho-substituents of the bromobenzene substrates and the existence of the $\mathrm{O} \cdots \mathrm{Pd}$ interaction between the carbonyl group and the palladium are beneficial to acquire high enantioselectivities.

\section{Experimental General procedure for the synthesis of amide substrates}

method A:<smiles>[R]NC(=O)c1cccc(CCC(C)C)c1Br</smiles>

Scheme 5: Method A for the synthesis of amide substrates.

Method A: To a stirred solution of 2-bromo-3-methylbenzoic acid (2.0 g, 1.0 equiv) in DMF ( 0.05 equiv), oxalyl chloride (1.5 equiv) was added in DCM $(20 \mathrm{~mL})$ at $0{ }^{\circ} \mathrm{C}$. After the addition was completed, the reaction mixture was further stirred for $2 \mathrm{~h}$ at room temperature. After the disappearance of the benzoic acid (monitored by TLC), the corresponding arylamines ( 1.5 equiv) were added, followed by the addition of triethyl- amine (2.0 equiv) in DCM $(10 \mathrm{~mL})$. After that the resulting reaction mixture was stirred for $20 \mathrm{~h}$ at room temperature and checked by TLC for reaction completion. The reaction mixture was then quenched with ice-cold water and extracted with DCM. The organic layer was washed with brine, dried over sodium sulfate and concentrated under reduced pressure to obtain the crude product. The crude product was purified by column chromatography to obtain the desired amide compounds.

method B:

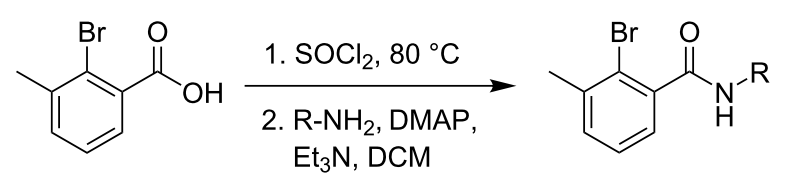

Scheme 6: Method B for the synthesis of amide substrates.

Method B: A round bottom flask $(100 \mathrm{~mL})$ was charged with 2-bromo-3-methylbenzoic acid (2.0 g, 1.0 equiv) and $\mathrm{SOCl}_{2}$ $(16 \mathrm{~mL})$ was added at room temperature. Then, the reaction mixture was refluxed at $80{ }^{\circ} \mathrm{C}$ for $2 \mathrm{~h}$. After completion of the reaction, the excess thionyl chloride was removed by evaporation using a rotary evaporator. Then, the corresponding arylamines (1.2 equiv) were added to the acyl chlorides, triethylamine (1.5 equiv) and DMAP (5 mol \%) in DCM (20 mL). The resulting reaction mixture was stirred for $20 \mathrm{~h}$ at room temperature. The completion of the reaction was monitored by TLC. After completion of the reaction ice-cold water was added and the separated organic layer was washed with brine and saturated sodium bicarbonate solution. Then, the organic layer was dried over anhydrous sodium sulfate and concentrated under reduced pressure to obtain the crude product. The crude product was purified by column chromatography to obtain the desired products.

\section{General procedure for the asymmetric Suzuki-Miyaura coupling}

In a glovebox, an oven-dried sealing tube $(15 \mathrm{~mL})$ was charged with bromoarylamides ( $0.2 \mathrm{mmol}, 1.0$ equiv), $\mathrm{Pd}_{2}(\mathrm{dba})_{3}$ (0.005 mmol, $5 \mathrm{~mol} \%$ Pd), ligand $\mathbf{L} 7$ (0.012 mmol, $6 \mathrm{~mol} \%$ ), arylboronic acid ( $0.4 \mathrm{mmol}, 2.0$ equiv), $\mathrm{K}_{3} \mathrm{PO}_{4}(0.6 \mathrm{mmol}$, 3.0 equiv) and $2 \mathrm{~mL}$ of dry THF. S-Phos was used as ligand for the preparation of racemic products and all the reactions were carried out at $50{ }^{\circ} \mathrm{C}$ for $72 \mathrm{~h}$. The completion of the reaction was checked by TLC. After completion of the reaction, the reaction mixture was cooled to room temperature and water was added. Then, the reaction mixture was extracted with ethyl acetate and the organic layer was dried over anhydrous $\mathrm{Na}_{2} \mathrm{SO}_{4}$ and concentrated under reduced pressure to obtain the crude product. The crude product was purified by flash chromatogra- 
phy using silica gel. The enantiomeric excess value of the product was determined by HPLC by using an AD-H, OD-H or IA-3 column.

\section{Supporting Information}

\section{Supporting Information File 1}

Further experimental data, copies of NMR spectra and HPLC chromatograms.

[https://www.beilstein-journals.org/bjoc/content/ supplementary/1860-5397-16-85-S1.pdf]

\section{Funding}

We are grateful for financial support from the National Natural Science Foundation of China (NSFC) (20972196, 21272283), Guangdong Province Zhu Jiang Talents Plan (2016ZT06C090) and Guangzhou City Talents Plan (CYLJTD-201609).

\section{ORCID ${ }^{\circledR}$ iDs}

Liqin Qiu - https://orcid.org/0000-0003-1703-3530

\section{References}

1. Zehm, D.; Fudickar, W.; Hans, M.; Schilde, U.; Kelling, A.; Linker, T. Chem. - Eur. J. 2008, 14, 11429-11441. doi:10.1002/chem.200801355

2. Clayden, J.; Moran, W. J.; Edwards, P. J.; LaPlante, S. R. Angew. Chem., Int. Ed. 2009, 48, 6398-6401. doi:10.1002/anie.200901719

3. LaPlante, S. R.; Fader, L. D.; Fandrick, K. R.; Fandrick, D. R.; Hucke, O.; Kemper, R.; Miller, S. P. F.; Edwards, P. J. J. Med. Chem 2011, 54, 7005-7022. doi:10.1021/jm200584g

4. Smyth, J. E.; Butler, N. M.; Keller, P. A. Nat. Prod. Rep. 2015, 32, 1562-1583. doi:10.1039/c4np00121d

5. Hubbard, B. K.; Walsh, C. T. Angew. Chem., Int. Ed. 2003, 42, 730-765. doi:10.1002/anie.200390202

6. Watanabe, T.; Tanaka, Y.; Shoda, R.; Sakamoto, R.; Kamikawa, K.; Uemura, M. J. Org. Chem. 2004, 69, 4152-4158. doi:10.1021/jo049600x

7. Bringmann, G.; Price Mortimer, A. J.; Keller, P. A.; Gresser, M. J.; Garner, J.; Breuning, M. Angew. Chem., Int. Ed. 2005, 44, 5384-5427. doi:10.1002/anie.200462661

8. Kozlowski, M. C.; Morgan, B. J.; Linton, E. C. Chem. Soc. Rev. 2009, 38, 3193-3207. doi:10.1039/b821092f

9. Bringmann, G.; Gulder, T.; Gulder, T. A. M.; Breuning, M. Chem. Rev. 2011, 111, 563-639. doi:10.1021/cr100155e

10. Bencivenni, G. Synlett 2015, 26, 1915-1922. doi:10.1055/s-0034-1378712

11. Wencel-Delord, J.; Panossian, A.; Leroux, F. R.; Colobert, F. Chem. Soc. Rev. 2015, 44, 3418-3430. doi:10.1039/c5cs00012b

12. Uozumi, Y.; Matsuura, Y.; Arakawa, T.; Yamada, Y. M. A. Angew. Chem., Int. Ed. 2009, 48, 2708-2710. doi:10.1002/anie.200900469

13. Shen, X.; Jones, G. O.; Watson, D. A.; Bhayana, B.; Buchwald, S. L. J. Am. Chem. Soc. 2010, 132, 11278-11287. doi:10.1021/ja104297g
14. Egami, H.; Matsumoto, K.; Oguma, T.; Kunisu, T.; Katsuki, T. J. Am. Chem. Soc. 2010, 132, 13633-13635. doi:10.1021/ja105442m 15. Link, A.; Sparr, C. Angew. Chem., Int. Ed. 2014, 53, 5458-5461. doi:10.1002/anie.201402441

16. Chen, Y.-H.; Cheng, D.-J.; Zhang, J.; Wang, Y.; Liu, X.-Y.; Tan, B. J. Am. Chem. Soc. 2015, 137, 15062-15065. doi:10.1021/jacs.5b10152

17. Mori, K.; Ichikawa, Y.; Kobayashi, M.; Shibata, Y.; Yamanaka, M.; Akiyama, T. J. Am. Chem. Soc. 2013, 135, 3964-3970. doi:10.1021/ja311902f

18. Barrett, K. T.; Miller, S. J. J. Am. Chem. Soc. 2013, 135, 2963-2966. doi:10.1021/ja400082x

19. Ros, A.; Estepa, B.; Ramírez-López, P.; Álvarez, E.; Fernández, R.; Lassaletta, J. M. J. Am. Chem. Soc. 2013, 135, 15730-15733. doi:10.1021/ja4087819

20. Bhat, V.; Wang, S.; Stoltz, B. M.; Virgil, S. C. J. Am. Chem. Soc. 2013, 135, 16829-16832. doi:10.1021/ja409383f

21. Shirakawa, S.; Wu, X.; Maruoka, K. Angew. Chem., Int. Ed. 2013, 52, 14200-14203. doi:10.1002/anie.201308237

22. Shimizu, H.; Nagasaki, I.; Saito, T. Tetrahedron 2005, 61, 5405-5432. doi:10.1016/j.tet.2005.03.022

See for a review of chiral biaryl-type bisphosphine ligands.

23. Hayashi, T.; Hayashizaki, K.; Kiyoi, T.; Ito, Y. J. Am. Chem. Soc. 1988, 110, 8153-8156. doi:10.1021/ja00232a030

24. Hayashi, T.; Niizuma, S.; Kamikawa, T.; Suzuki, N.; Uozumi, Y. J. Am. Chem. Soc. 1995, 117, 9101-9102. doi:10.1021/ja00140a041

25. Genov, M.; Almorín, A.; Espinet, P. Tetrahedron: Asymmetry 2007, 18, 625-627. doi:10.1016/j.tetasy.2007.03.001

26. Genov, M.; Fuentes, B.; Espinet, P.; Pelaz, B. Tetrahedron: Asymmetry 2006, 17, 2593-2595. doi:10.1016/j.tetasy.2006.10.008

27. Miyaura, N.; Suzuki, A. Chem. Rev. 1995, 95, 2457-2483. doi:10.1021/cr00039a007

28. Martin, R.; Buchwald, S. L. Acc. Chem. Res. 2008, 41, 1461-1473. doi:10.1021/ar800036s

29. Baudoin, O. Eur. J. Org. Chem. 2005, 4223-4229. doi:10.1002/ejoc.200500394

30. Zhang, D.; Wang, Q. Coord. Chem. Rev. 2015, 286, 1-16. doi:10.1016/j.ccr.2014.11.011

31. Bringmann, G.; Walter, R.; Weirich, R. Angew. Chem., Int. Ed. Engl. 1990, 29, 977-991. doi:10.1002/anie.199009771

32. Stanforth, S. P. Tetrahedron 1998, 54, 263-303. doi:10.1016/s0040-4020(97)10233-2

33. Hassan, J.; Sévignon, M.; Gozzi, C.; Schulz, E.; Lemaire, M. Chem. Rev. 2002, 102, 1359-1470. doi:10.1021/cr000664r

34. Bedford, R. B.; Cazin, C. S. J.; Holder, D. Coord. Chem. Rev. 2004, 248, 2283-2321. doi:10.1016/j.ccr.2004.06.012

35. Denmark, S. E.; Sweis, R. F. Acc. Chem. Res. 2002, 35, 835-846. doi:10.1021/ar020001r

36. Miyaura, N.; Yamada, K.; Suzuki, A. Tetrahedron Lett. 1979, 20 , 3437-3440. doi:10.1016/s0040-4039(01)95429-2

37. Cammidge, A. N.; Crépy, K. V. L. Chem. Commun. 2000, 1723-1724. doi:10.1039/b004513f

38. Cammidge, A. N.; Crépy, K. V. L. Tetrahedron 2004, 60, 4377-4386. doi:10.1016/j.tet.2003.11.095

39. Yin, J.; Buchwald, S. L. J. Am. Chem. Soc. 2000, 122, 12051-12052. doi:10.1021/ja005622z

40. Zhao, Q.; Li, C.; Senanayake, C. H.; Tang, W. Chem. - Eur. J. 2013, 19, 2261-2265. doi:10.1002/chem.201203898

41. Li, C.; Chen, T.; Li, B.; Xiao, G.; Tang, W. Angew. Chem., Int. Ed. 2015, 54, 3792-3796. doi:10.1002/anie.201411518 
42. Tang, W.; Patel, N. D.; Xu, G.; Xu, X.; Savoie, J.; Ma, S.; Hao, M.-H.; Keshipeddy, S.; Capacci, A. G.; Wei, X.; Zhang, Y.; Gao, J. J.; Li, W.; Rodriguez, S.; Lu, B. Z.; Yee, N. K.; Senanayake, C. H. Org. Lett. 2012, 14, 2258-2261. doi:10.1021/ol300659d

43. Xu, G.; Fu, W.; Liu, G.; Senanayake, C. H.; Tang, W. J. Am. Chem. Soc. 2014, 136, 570-573. doi:10.1021/ja409669r

44. Bronger, R. P. J.; Guiry, P. J. Tetrahedron: Asymmetry 2007, 18, 1094-1102. doi:10.1016/j.tetasy.2007.04.020

45. Bermejo, A.; Ros, A.; Fernandez, R.; Lassaletta, J. M. J. Am. Chem. Soc. 2008, 130, 15798-15799. doi:10.1021/ja8074693

46. Yamamoto, T.; Akai, Y.; Nagata, Y.; Suginome, M. Angew. Chem., Int. Ed. 2011, 50, 8844-8847. doi:10.1002/anie.201103792

47. Jensen, J. F.; Johannsen, M. Org. Lett. 2003, 5, 3025-3028. doi:10.1021/ol034943n

48. Zhang, S.-S.; Wang, Z.-Q.; Xu, M.-H.; Lin, G.-Q. Org. Lett. 2010, 12, 5546-5549. doi:10.1021/ol102521q

49. Yang, X.; Xu, G.; Tang, W. Tetrahedron 2016, 72, 5178-5183. doi:10.1016/j.tet.2015.12.051

50. Ma, Y.-N.; Yang, S.-D. Chem. - Eur. J. 2015, 21, 6673-6677. doi:10.1002/chem.201406554

51. Ros, A.; Estepa, B.; Bermejo, A.; Álvarez, E.; Fernández, R.; Lassaletta, J. M. J. Org. Chem. 2012, 77, 4740-4750. doi:10.1021/jo300548z

52. Sawai, K.; Tatumi, R.; Nakahodo, T.; Fujihara, H. Angew. Chem., Int. Ed. 2008, 47, 6917-6919. doi:10.1002/anie.200802174

53. Benhamou, L.; Besnard, C.; Kündig, E. P. Organometallics 2014, 33, 260-266. doi:10.1021/om4009982

54. Li, Y.; Tang, J.; Gu, J.; Wang, Q.; Sun, P.; Zhang, D. Organometallics 2014, 33, 876-884. doi:10.1021/om400825e

55. Wu, L.; Salvador, A.; Ou, A.; Shi, M. W.; Skelton, B. W.; Dorta, R. Synlett 2013, 24, 1215-1220. doi:10.1055/s-0033-1338864

56. Genov, M.; Almorín, A.; Espinet, P. Chem. - Eur. J. 2006, 12, 9346-9352. doi:10.1002/chem.200600616

57. Patel, N. D.; Sieber, J. D.; Tcyrulnikov, S.; Simmons, B. J.; Rivalti, D.; Duvvuri, K.; Zhang, Y.; Gao, D. A.; Fandrick, K. R.; Haddad, N.; Lao, K. S.; Mangunuru, H. P. R.; Biswas, S.; Qu, B.; Grinberg, N.; Pennino, S.; Lee, H.; Song, J. J.; Gupton, B. F.; Garg, N. K.; Kozlowski, M. C.; Senanayake, C. H. ACS Catal. 2018, 8 , 10190-10209. doi:10.1021/acscatal.8b02509

58. Uozumi, Y.; Matsuura, Y.; Suzuka, T.; Arakawa, T.; Yamada, Y. M. A. Synthesis 2017, 49, 59-68. doi:10.1055/s-0036-1589407

59. Shen, D.; Xu, Y.; Shi, S.-L. J. Am. Chem. Soc. 2019, 141, 14938-14945. doi:10.1021/jacs.9b08578

60. Wang, S.; Li, J.; Miao, T.; Wu, W.; Li, Q.; Zhuang, Y.; Zhou, Z.; Qiu, L. Org. Lett. 2012, 14, 1966-1969. doi:10.1021/ol300721p

61. Wu, W.; Wang, S.; Zhou, Y.; He, Y.; Zhuang, Y.; Li, L.; Wan, P.; Wang, L.; Zhou, Z.; Quu, L. Adv. Synth. Catal. 2012, 354, 2395-2402. doi:10.1002/adsc.201200095

62. Zhou, Y.; Wang, S.; Wu, W.; Li, Q.; He, Y.; Zhuang, Y.; Li, L.; Pang, J.; Zhou, Z.; Qiu, L. Org. Lett. 2013, 15, 5508-5511. doi:10.1021/ol402666p

63. Xia, W.; Li, Y.; Zhou, Z.; Chen, H.; Liang, H.; Yu, S.; He, X.; Zhang, Y.; Pang, J.; Zhou, Z.; Qu, L. Adv. Synth. Catal. 2017, 359, 1656-1662. doi:10.1002/adsc.201700020

64. Zhou, Y.; Zhang, X.; Liang, H.; Cao, Z.; Zhao, X.; He, Y.; Wang, S.; Pang, J.; Zhou, Z.; Ke, Z.; Qiu, L. ACS Catal. 2014, 4, 1390-1397. doi:10.1021/cs500208n
65. Xia, W.; Zhang, Z.-W.; Li, Y.; Jiang, X.; Liang, H.; Zhang, Y.; Cao, R.; Qiu, L. Org. Biomol. Chem. 2019, 17, 2351-2355.

doi:10.1039/c8ob03048k

66. Kim, S.-T.; Kim, S.; Baik, M.-H. Chem. Sci. 2020, 11, 1017-1025. doi:10.1039/c9sc03095f

\section{License and Terms}

This is an Open Access article under the terms of the Creative Commons Attribution License (http://creativecommons.org/licenses/by/4.0). Please note that the reuse, redistribution and reproduction in particular requires that the authors and source are credited.

The license is subject to the Beilstein Journal of Organic Chemistry terms and conditions:

(https://www.beilstein-journals.org/bjoc)

The definitive version of this article is the electronic one which can be found at: doi:10.3762/bjoc. 16.85 